\title{
Effects of Goyazensolide during in Vitro Cultivation of Schistosoma mansoni
}

\section{Léo Roberto Barth, Ana Paula Moraes Fernandes*, João Tadeu Ribeiro-Paes, Vanderlei Rodrigues ${ }^{+}$}

\author{
Departamento de Parasitologia, Microbiologia e Imunologia, Faculdade de Medicina de Ribeirão Preto, Av. \\ Bandeirantes 3900, 14049-900 Ribeirão Preto, SP, Brasil
}

Goyazensolide, a component extracted of Eremanthus goyazensis showed a significant inhibitory effect on egg-laying of Schistosoma mansoni during in vitro cultivation of this parasite. Motility of the worms was also reduced under treatment with goyazensolide and $90 \%$ of mortality was reached with concentrations up to $4 \mu \mathrm{g} / \mathrm{ml}$. It has found that separated worms were more susceptible than worms pairing during drug exposition and female alone was significantly more susceptible than male worm in the same conditions of in vitro cultivation.

Natural products isolated from plants represent potential sources for the identification of structures useful for the design of alternative molecules to be used as new drug substances against several infectious diseases.

Key words: Schistosoma mansoni - schistosomiasis - sesquiterpene lactones - in vitro cultivation

Schistosomiasis is a chronic debilitanting disease representing the second most prevalent tropical disease affecting more than 200 million people worldwilde. Chemotherapy and the reduction of transmission are presentely the two main actions in the control of schistosomiasis and this situation is unlikely to change until a suitable vaccine becomes available (Modha et al. 1990). It is essential therefore that effective anti-schistosome drugs are available and that the search continues for new chemotherapeutic agents to combat the emergence of drug resistance such as oxaminiquine (Lambertucci et al. 1980, Souza et al. 1982).

Plants have provided a number of useful clinical agents and have considerable potential as sources of new drugs, not only in their pharmacological or chemotherapeutic effects, but also in their role as template molecules with a chemical structure showing the required biological activity, and subsequent development of this lead strucutre into a safe and therapeutically effective form (Phillipson 1994).

Sesquiterpene lactones form one of the largest group of cytotoxic and anti-tumor compounds of plant origin (Picman 1986). Various studies suggested that these secondary plant metabolites play

Research supported by CNPq and FINEP.

*FAPESP fellowship

${ }^{+}$Corresponding author. Fax: +55-16-633.6631

Received 5 November 1996

Accepted 19 December 1996 an important role in protection of plants against pathogenous organisms, herbivirous, insects, and mammals. Some purified sesquiterpene lactones were showed to have strong effects against pathogenic protozoa Entamoeba histolytica, Trichomonas vaginalis, Plasmodium falciparum and $P$. vivax (Picman 1986).

The schistosomicidal activity of these compounds has been demonstrated when applied on skin. They provide protection against the infection by cercariae of Schistosoma mansoni (Pellegrino 1967) and inhibition of egg-laying and movement by adult pairs of $S$. japonicum in vitro (Jisaka et al. 1992).

The present in vitro studies were undertaken to examine the antischistosomal effects of the goyazensolide on the adult $S$. mansoni.

\section{MATERIALS AND METHODS}

The LE strain of $S$. mansoni was routinely maintained in laboratory by passage through Biomphalaria glabrata snails and Balb/c mice. Infection of mice weighing 20-30 g was carried out percutaneously with aproximately 150 cercariae of S. mansoni.

Adult schistosomes were recovered from the mesenteric and portal veins of mice infected seven weeks previously under asseptic conditions using dissecting needles. The parasites were washed in RPMI-1640 medium (Cutilab) buffered to pH 7.5 with HEPES $20 \mu \mathrm{M}$ and supplemented with penicilin $(100 \mathrm{U} / \mathrm{ml})$, streptomycin $(100 \mu \mathrm{g} / \mathrm{ml})$, and $10 \%$ fetal calf serum (Gibco). Each worm pair was transferred to $35 \mathrm{~mm}$ diameter $(35 \times 10$ 
$\mathrm{mm}$ ) polystyrene dishes (Nunc, Denmark) with $2 \mathrm{ml}$ of the same medium. Worms which became separated from their partners during the recovery procedure were discarded; incubation was carried out at $37^{\circ} \mathrm{C}$ in a humid atmosphere containing $5 \% \mathrm{CO}_{2}$ in the dark.

Goyazensolide powder was kindly supplied by Drs JJ Calegari Lopes and W Vichenwski (Faculty of Pharmacy, Department of Physics and Chemistry, Ribeirão Preto, State of São Paulo). For in vitro tests with schistosomes the goyazensolide was dissolved in dimethyl sulfoxide (DMSO) and then tapped up with distilled water to the desired concentration of stock and sterilized by passage through a millipore filter of $0.45 \mu \mathrm{m}$ pore size. Appropriate dilutions of this stok solution were made with sterilized distilled water so that a constant $100 \mu \mathrm{l}$ volume of drug solution was added to $2 \mathrm{ml}$ of medium in each assay dish.

Control worms were treated with $10 \%$ of DMSO in sterile distilled water and the worms viability (i.e. motility) were inspected visually. Egg production was measured daily by manual counting under a inverted microscope (Leitz, Diavert).

\section{RESULTS}

The viability of $S$. mansoni adult worms was observed during in vitro incubation with various concentrations of goyazensolide. Fig. 1 shows that the exposure to the drug resulted in the death of the organisms and this lethal effect was dependent of drug concentration and time incubation.

In the first $24 \mathrm{hr}$ of drug exposure more than $90 \%$ of the parasites were dead at concentrations of 3.5 and $4 \mu \mathrm{g} / \mathrm{ml}$ and with 2 and $3 \mu \mathrm{g} / \mathrm{ml}$; a cumulative effect could be observed, since the mortality levels of $5 \%$ and $45 \%$ in the first $24 \mathrm{hr}$ with those concentrations reached levels of 50\% and $95 \% 24$ hr later.

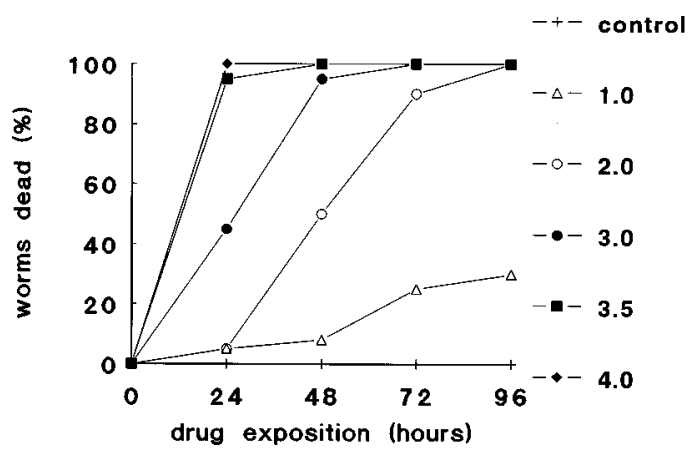

Fig. 1: viability of schistosomes following different concentrations and time exposition of goyazensolide. A pair of worms were incubated in vitro with goyazensolide at concentrations $(\mu \mathrm{g} / \mathrm{ml})$ showed in figure legends. Each point in the figure represents the mean of triplicate determinations of percentage of dead worms.
The control group containing $10 \%$ of DMSO was not affected for up to $96 \mathrm{hr}$ of observation and all worms remained paired throughout the observation period and exhibited vigorous activity, especially a continous flexing of anterior regions. Light microscope observations of whole worms showed a progressive tegumental vesiculation of the parasites, analogous to the tegumental ballooning observed with Astiban (Shaw \& Erasmus 1977); the amount and extent of this damage was proportional to the time exposure and drug concentration.

In order to determine the sensitivity of each sex, male and female adult worms were mechanically separated and incubated with $2 \mu \mathrm{g} / \mathrm{ml}$ of the drug. As shown in Fig. 2, separated worms were more susceptible than paired worms and the effect was more proeminent in the first $24 \mathrm{hr}$ in which $8.3 \%$ of worms pairs were dead in contrast to $40.5 \%$ of female and $34.2 \%$ of males which dead in the same period. In this experiment, it was also clear that female worms alone were significantly more susceptible than male worms to goyazensolide killing.

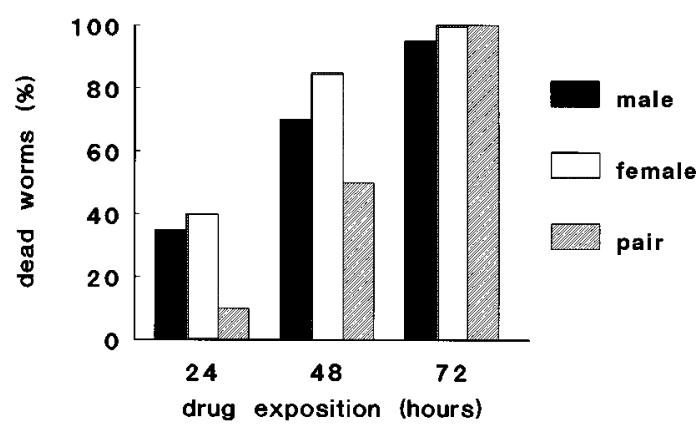

Fig. 2: effect of goyazensolide on coupled and unpaired worms in vitro. Worms pair, female and male were incubated with $2 \mu \mathrm{g} /$ $\mathrm{ml}$ of the drug. The bars represent percentage of dead worms.

The effect of goyazensolide on daily egg production by adult worms pairs is showed in Fig. 3 . There was a significant and progressive reduction in egg output by worms maintained in increasing concentrations of goyazensolide. The effect was observed after $24 \mathrm{hr}$ of drug exposure where the control group showed an increase egg output from 18 eggs in the first day to 43 eggs per day by worm pair on the second and third days and this increase was significantly reduced by goyazensolide with concentrations up to $0.8 \mu \mathrm{g} / \mathrm{ml}$.

Concentrations of goyazensolide higher than $0.8 \mu \mathrm{g} / \mathrm{ml}$ resulted in a dramatic reduction of egg production, but in this case the motility of the worms was also markedly reduced by separating adult pairs. 


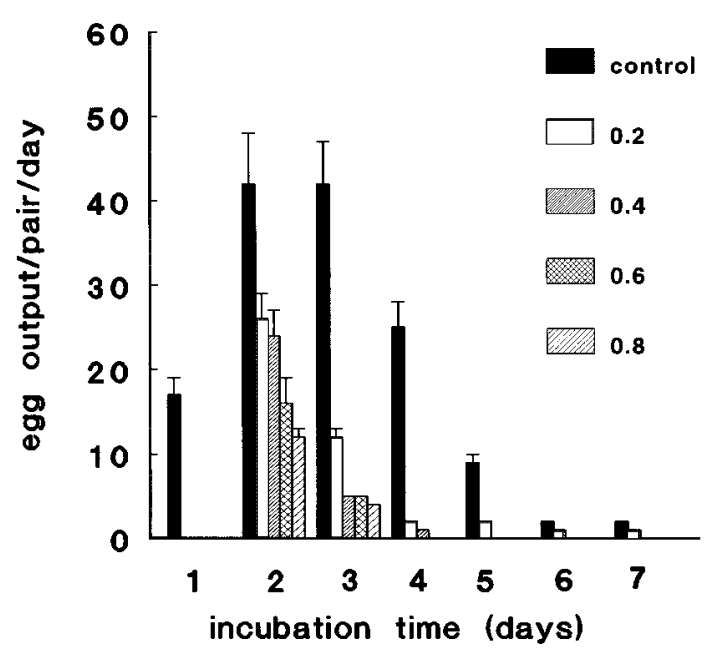

Fig. 3: effect of goyazensolide on egg output in vitro. Adult worms pairs were incubated with goyazensolide at the concentrations $(\mu \mathrm{g} / \mathrm{ml})$ showed in figure legends. The drug was added at the end of the first day cultivation The bars represent the average of sextuplicate determinations \pm SD of eggs per day.

\section{DISCUSSION}

The importance of natural product molecules to medicine lies not only in their pharmacological or chemotherapeutic effects, but also in their role as template molecules for the production of new drug substances (Phillipson 1994).

The majority of sesquiterpene lactones are common constituents in members of the Asteraceae (Rodriguez et al. 1976). There have been several reports of anti-bacterial, anti-fungal and anti-protozoan activities of these compounds (Picman 1986). Some protection against infection by $S$. mansoni was demonstrated with extracts of certain Brazilian trees of the Asteraceae family (Gilbert et al. 1970, Picman 1986) and a reduction of egg-laying in vitro have been demonstrated on S. japonicum (Jisaka et al. 1992).

The present work shows that goyazensolide, a component extracted of Eremanthus goyazensis had a significant inhibitory effect on egg-laying of $S$. mansoni in vitro and this effect was dependent on the duration of exposure and drug concentration. Also, one complete bloking of motility of the parasites was observed with concentrations higher than those used to reduce the egg output.

Although the mechanisms responsible for oogenesis in this parasite is not known, probably some event related to this process is firstly affected by the goyazensolide without affecting the pairing and motility of the worms. Also, it was observed a sig- nificant difference in parasite susceptibility in situations where the worms were separated from their partner.

The fact that female schistosomes are more susceptible to goyazensolide raised the question of whether the observed effect on females is a direct consequence of drug action or in combination with the apparent loss of some stimulus which is essential for normal female pairing.

\section{ACKNOWLEDGEMENTS}

To Vania Fernandes and Olinda M Trevilato for expert technical assistance.

\section{REFERENCES}

Gilbert B, deSouza JR, Fascio M, Kitagawa M, Nascimento SCC, Fortes CC, Pellegrino J 1970. Esquistossomose: Proteção contra infecção por terpenóides. An Acad brasil Cienc 42 (Suppl.): 397400.

Jisaka M, Kawanaka M, Sugiyama H, Takegawa K, Huffman MA, Ohigashi H, Koshizu K 1992. Antischistosomal activities of sesquiterpene lactones and steroid glucosides from Vernonia amygdalina, possibly used by wild chimpanzees against parasite-related diseases. Biosc Biothec Biochem 56: 845846.

Lambertucci JR, Pedroso ERP, Souza DWC, Lim DP, Neves J, Salazar HM, Marinho RP, Rocha MOC, Coelho PMS, Costa MFFL, Greco DB 1980. Therapeutic efficacy of oral oxamniquine in the toxaemic form of Schistosoma mansoni: treatment of eleven individues from two families and experimental study. Am J Trop Med Hyg 29: 50-53.

Modha J, Lambertucci JR, Doenhoff MJ, Mclaren DJ 1990. Immune dependence of schistosomicidal chemotherapy: an ultrastructural study of Schistosoma mansoni adult worms exposed to praziquantel immune serum in vivo. Parasite Immunol 12:321-334.

Pellegrino J 1967. Protection against human schistosome cercariae. Exp Parasitol 21: 112-131.

Phillipson JD 1994. Natural products as drugs. Trans $R$ Soc Trop Med Hyg 88: 17-19.

Picman AK 1986. Biological activities of sesquiterpene lactones. Biochem Syst Ecol 14: 255-281.

Rodriguez F, Towers GHN, Mitchell JC 1976. Biological activities of sesquiterpene lactones. Phytochemistry 15: 1573-1580.

Shaw MK, Erasmus DA 1977. Schistosoma mansoni: Differential cell death associated with in vitro culture and treatment with Astiban (Roche). Parasitology 75: 101-109.

Souza LCD, Pedro RJ, Deberaldin ER 1982. Use of praziquantel in patients with schistosomiasis mansoni previously treated with oxaminiquine and/ or hycanthone: resistance of Schistosoma mansoni to schistosomicidal agents. Trans $R$ Soc Trop Med Hyg 76: 652-659. 
430 In vitro Cultivation of S. mansoni - LR Barth et al. 